\title{
Are Clinics a Magic Bullet?
}

\author{
DEBORAH J. CANTRELL ${ }^{*}$
}

In the current conversation about reforming legal education, one of the constant refrains is that law schools must graduate students who are "practice ready." Commentators go on to argue that for law schools to produce "practice ready" students, they must expand how they offer experiential learning. One potential way to do that is to expand clinical legal education programs. I worry that law schools (and others) are envisioning clinical legal education as a magic bullet that will solve all of the ills and imbalances present in current legal education. In this article, I demonstrate the unhelpfulness of the phrase "practice ready," and dismantle the idea that clinical legal education, or any other singularly-focused intervention, can transform legal education. Building from key insights already made in clinical legal pedagogy, I offer an alternative vision of legal education as an ecology of learning, in which law school as a whole is understood to be an interconnected and interdependent system that is dynamic, changing, and in action. I articulate how understanding law school as an ecology of learning can advance innovative changes - both small and large - leading to graduates who have better chances of flourishing in the legal profession.
Dans le débat actuel sur la réforme de la formation juridique, une des constantes est le fait que les écoles de droit doivent produire des diplômés «prêts à pratiquer». Les commentateurs prétendent que pour produire des étudiants "prêts à pratiquer», les écoles de droit doivent élargir leur manière d'offrir l'apprentissage par l'expérience. Une manière éventuelle d'y arriver serait d'élargir les programmes de formation juridique clinique. Je m'inquiète du fait que les écoles de droit (et les autres) envisagent la formation juridique clinique comme une solution magique à tous les maux et malaises de la situation actuelle. Dans cet article, je démontre l'inutilité de l'expression "prêt à pratiquer» et je défais l'idée que la formation juridique clinique, ou toute intervention à but unique puisse transformer la formation juridique. À partir de connaissances clés déjà en place dans la pédagogie juridique clinique, je propose une autre vision de la formation juridique en tant qu'écologie de l'apprentissage, c'est-à-dire une vision où l'école de droit, dans son ensemble, est un système interconnecté et interdépendant dynamique, changeant et actif. J'explique comment une école de droit, en tant qu'écologie de l'apprentissage, peut faire évoluer les changements novateurs, à la fois petits et grands, afin que les diplômés aient de meilleures chances de s'épanouir dans la profession juridique.

\section{TABLE OF ConTENTS}

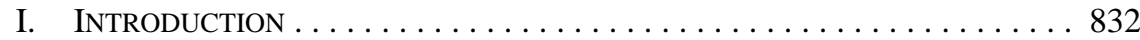

II. WHAT HAS THE CONVERSATION ABOUT CHANGING

LEGAL EDUCATION LOOKED LiKE THUS FAR? . . . . . . . . . . . . . . 833

III. WHERE DO CliniCS Fit INTO THE CONVERSATION? . . . . . . . . . . . . 836

IV. WHAT IS A LEARNING ECOLOGY AND WHAT WOULD IT

MEAN TO Consider A LAW SCHOOL AS OnE? . . . . . . . . . . . . 838

V. WhAT SHOULD BE THE GOALS OF A LAW SCHOOL LEARNING ECOLOGY AND WHAT DOES THAT MEAN IN ACTION? . . . . . . 840

V. CONCLUSION . . . . . . . . . . . . . . . . . . . . . . . . . . . . 847 


\section{INTRODUCTION}

Since there has been legal education, there has been a conversation about how it should change. ${ }^{1}$ The conversation has intensified over the last handful of years in large part brought about by the confluence of increasing law school tuition, greater numbers of law school graduates, and the Great Recession. ${ }^{2}$ As is abundantly clear, law schools are under sustained pressure to "do something" about the fact that an uncomfortable number of law school graduates incurred notable debt to go to school and now are un- or under-employed and facing rickety financial futures. Every law school hopes it will be the one to discover the "do something” magic bullet.

Throughout the legal education reform conversation, I have seen at least two themes appear repeatedly. One is that the goal of legal education should be to produce "practice ready" graduates. ${ }^{3}$ The other theme builds on the first, and argues that producing "practice ready” lawyers happens most effectively through experiential learning — especially through intensive experiential learning courses like clinics. ${ }^{4}$ In this article I explore whether those calling for "practice ready" graduates have an agreed-upon definition for what counts as "practice ready.” Not surprisingly, I conclude they do not, and that there seem to be three different definitions. However, I further conclude that under all of the three definitions, clinics have taken on an aura of being the magic bullet — to cheers for some, and to dismay and distress for others. The conversation is becoming rigid and zero-sum.

In this article, I want to return to the genuine concerns underlying the conversation about how to reform legal education - how do we, the teachers, make sure that how we do our teaching benefits our students in ways that are useful to them as they seek to lead flourishing lives, professionally and personally? I suggest that we need to think about our law schools as learning ecologies - interconnected and interdependent systems that are dynamic, changing, and in action. Embracing the idea of a learning ecology helps us to see that no one part of the ecology can be a magic bullet. Every piece of the ecology, by definition, is important, and, by definition, is connected and interdependent. Thus, the task for us becomes how to more thoroughly and thoughtfully spread learning across the ecology.

In order to move forward, we also have to understand the goals of the ecology and how those goals are translated into particular actions. To do that for a law school learning ecology, I suggest some goals that already have been articulated and adopted at law schools.

For a comprehensive historical account of legal education in the United States, its critiques, and the particular development of clinical legal education, see Margaret Martin Barry, Jon C Dubin \& Peter A Joy, “Clinical Education for This Millenium: The Third Wave” (2000) 7:1 Clinical L Rev 1. For a historical recounting of legal realist critiques of legal education and legal realist strands in clinical legal education, see Katherine R Kruse, “Getting Real About Legal Realism, New Legal Realism, and Clinical Legal Education” (2011) 56:2 NYL Sch L Rev 659. In this article, I focus on legal education in the US.

$2 \quad$ See e.g. David Segal, “Is Law School a Losing Game?” The New York Times (8 January 2011), online: The New York Times <http://www.nytimes.com/2011/01/09/business/09law.html>. The conversation also has been well chronicled in the blogosphere. For an example, see The Legal Whiteboard, maintained by three law professors: William D Henderson, Jeffrey M Lipshaw \& Michele De Stefano, eds, The Legal Whiteboard, online: Law Professors Blog Network <http://lawprofessors.typepad.com/legal whiteboard/>.

3 See generally Margaret Martin Barry, “Practice Ready: Are We There Yet?” (2012) 32:2 Boston College Journal of Law \& Social Justice 247 (describing the history of the "practice ready" theme).

$4 \quad$ See Phyllis Goldfarb, “Back to the Future of Clinical Legal Education” (2012) 32:2 Boston College Journal of Law \& Social Justice 279. 
I then translate those goals into actions by using the vocabulary of "competencies." ${ }^{5}$ I demonstrate that the predominant map of competencies taught now at most law schools is more limited than is useful to our students. Further, competencies unhelpfully are cabined into segments of law school. We focus on certain competencies in certain classes, but we generally fail to connect competencies across classes. Thus, instead of having a dynamic, interconnected, non-linear, ecology of learning, we have an atomized, rigid, and linear structure. While we might feel comfortable in our learning architecture, we are disserving our students. Throughout the article, I offer multiple examples of how a learning ecology can benefit our students.

\section{What has the Conversation About Changing LEGAL EDUCATION LOOKED LIKE THUS FAR?}

Commentators have noted several different features of law schools and law school financing that are causing law schools to "fail." Those features include inertia created by accreditation standards, decreased teaching loads for faculty while salaries have risen, and increased tuition costs to cover increased expenses such as higher faculty salaries. ${ }^{6}$ In this article, I focus on the question of whether and how law schools are failing to teach in effective ways. My core critique of the typical way in which law schools approach teaching is that they fail to understand the need to create an ecology of law learning. Schools fail to see that learning is not about acquiring a series of independent, free-standing skills or content, but is a deeply interconnected and relational enterprise. I note the irony that by focusing only on law school teaching and student learning, I too risk suggesting that improving law schools is just about improving a series of separate parts (like teaching or like reducing tuition) rather than understanding that law schools themselves are institutions within an even larger ecology of higher education. I try to note those moments where my recommendations would also need to be considered in light of a larger ecology. Let me now briefly sketch some of the prominent contours of the current conversation about legal education.

One of the most-heard demands made of law schools is that they should graduate students who are "practice ready." There is no standard definition of what constitutes "practice ready." However, with the economics of the traditional legal industry under sustained pressure, both law firms and legal aid firms wish that practice ready really could mean something closer to "practice proven." For traditional legal employers, it would be economically ideal if legal education changed in such a way that law students graduated with

See Marjorie M Shultz \& Sheldon Zedeck, "Predicting Lawyer Effectiveness: Broadening the Basis for Law School Admissions Decisions” (2011) 36:3 Law \& Soc Inquiry 620 (empirically discerning what the legal profession considered the most important competencies possessed by effective lawyers) [Shultz \& Zedeck, "Predicting Lawyer Effectiveness"].

$6 \quad$ See Brian Z Tamanaha, Failing Law Schools (Chicago: University of Chicago Press, 2012). See also Lauren Carasik, "Renaissance or Retrenchment: Legal Education at a Crossroads" (2011) 44:3 Ind L Rev 735.

See generally Barry, supra note 3 at 247-48; American Bar Association Resolution 10B, adopted 9 August 2011 (legal education providers should focus on making future lawyers practice ready); Roy Stuckey et al, Best Practices for Legal Education: A Vision and A Road Map, 1st ed (Clinical Legal Education Association, 2007) (while not using the phrase "practice ready," the underlying philosophy is to better prepare law students for law practice); William D Henderson, "Blueprint for Change" (2013) 40:2 Pepp L Rev 461 (opining that graduating "practice ready" students is "insufficient to cope with the structural changes occurring within the legal industry" at 501). 
the kinds of competencies employers generally see now in their early mid-level lawyers. For example, the role of clinics in the "practice proven" model is to replicate, as much as possible, what junior lawyers typically learn during their first few years in practice.

The hardened view of legal employers understands their call for the reform of legal education as self-interested and self-protective. ${ }^{8}$ If they can frame the "problem" entirely as about legal education, then legal employers can shift the entire cost of curing the problem onto law schools instead of bearing any of the cost burden themselves. Indeed, law schools have balked at proposals that reform legal education only by extensively expanding experiential learning, like clinics, complaining such reform is too costly. ${ }^{9}$

Whether legal employers are selfishly motivated or not, in order to discern how to allocate training responsibilities between law schools and legal employers, we need to explore further what contours "practice ready" might take. Some within legal education have embraced "practice ready" as a call for focused, technical skills training. ${ }^{10}$ Under that approach, law graduates should be able to show that they have completed some list of technical tasks by the time they finish school. For example, they should have drafted an advisory letter to a client, written and responded to a motion for summary judgment, drafted a commercial lease, argued a mock appeal, attended a mediation, and interviewed a mock client. Regardless of what technical tasks are on the list, the goal is for students to undertake specific actions in order to become "practice ready."

The technical approach to "practice ready" contains two critical assumptions. First, that the practice of law more often than not requires technical prowess (or, at least, that newer lawyers are deployed most often to answer technical questions). Second, that if law students have successfully completed a technical task in law school, they will be able to successfully complete that same kind of task again for their clients. Not surprisingly, those who embrace the technical approach see clinics as capstone courses that students take when they are ready to learn more advanced technical skills or to learn skills in combination. ${ }^{11}$

The technical approach also has embedded in it a sense of accountability on law schools. If there is a checklist of technical tasks that every law student should have mastered by graduation, then there must be a tangible way to hold law schools accountable for a set of

8 See Eric Miller, “The Cost of Apprenticeship” (1 March 2013), online: PrawfsBlawg <http://prawfsb lawg.blogs.com/prawfsblawg/2013/03/the-cost-of-apprenticeship.html>.

$9 \quad$ See e.g. Sharon L Beckman \& Paul R Tremblay, "Foreword: The Way to Carnegie” (2012) 32:2 Boston College Journal of Law \& Social Justice 215 ("[c]onventional wisdom says that, even if it is the most effective method of teaching productive and thoughtful lawyering, clinical legal education — along with many other forms of experiential teaching - is just too expensive to offer to a majority of law students" at 228-30). See also Henderson, supra note 7 (noting that legal reform focused only on expanding clinical education "is a very expensive solution" at 502).

10 See e.g. American Bar Association, Section of Legal Education and Admissions to the Bar, Report of the Outcome Measures Committee (27 July 2008), online: American Bar Association <http://apps. americanbar.org/legaled/committees/subcomm/Outcome\%20Measures\%20Final\%20Report.pdf> [Outcome Measures] (advising that law schools should focus on learning outcomes of their students using other professional fields with specific learning outcomes as examples).

11 See e.g. Carolyn Grose, "Beyond Skills Training, Revisited: The Clinical Education Spiral” (2013) 19:2 Clinical L Rev 489 (opining that a clinic is the "pinnacle of the legal education pyramid” at 512). 
quantifiable outcomes. ${ }^{12}$ Similarly, clinics should have checklists of technical tasks that their students will have mastered by the time the student concludes the clinic course.

The notable contrasting view to the technical approach is what I will call the mindset approach to "practice readiness.” Under that approach, the goal is to use content knowledge, such as substantive law and technical skills, as the material to be used in activities that cultivate a nimble, adaptive, creative, and thoughtful mindset. I think many faculty who teach clinical courses would say that a mindset approach is the defining feature of "clinical" pedagogy. ${ }^{13}$ The mindset approach is inspired by theories from multiple disciplines. For example, the work of adult learning theorist Donald Schön is often cited. ${ }^{14}$ Schön detailed how expert professionals learned using reflective practices in which they take in information, frame the situation, reflect on new or additional information, then reframe the problem, in an iterative, interactive process. ${ }^{15}$

Similarly, the mindset approach evinces psychologist Carol Dweck's work on fixed and growth mindsets. ${ }^{16}$ Dweck argues that how people respond to personal successes and failures often depends on their understanding of ability. Those who believe ability is an innate personality characteristic understand success and failure as constrained by those innate characteristics (or "fixed"). ${ }^{17}$ Those who understand ability to be based on effort and exploration understand ability to be mutable and learnable (or "grow-able"). ${ }^{18}$ Dweck's research demonstrated that people with growth mindsets responded more positively and productively to failures than did people with fixed mindsets. ${ }^{19}$ Her research also demonstrated that people can cultivate a growth mindset. ${ }^{20}$

One final example of how the mindset approach is infused by many sources is the fairly recent introduction of "mindfulness" practices in some law schools. ${ }^{21}$ Typically, mindfulness practices in law school settings have prioritized helping a person with focus and attention, with discerning options and choices of actions, and with developing steadiness in the face

See e.g. Outcome Measures, supra note 10 (discussing how moving to outcome measurements ensures better legal education at 54-60).

See e.g. David F Chavkin, Clinical Legal Education: A Textbook for Law School Clinical Programs (Cincinnati: Anderson, 2002).

Ibid.

15 See generally, Donald A Schön, The Reflective Practitioner: How Professionals Think in Action (New York: Basic Books, 1983); Donald A Schön, Educating the Reflective Practitioner: Toward a New Design for Teaching and Learning in the Professions (San Francisco: Jossey-Bass, 1987). See generally Carol S Dweck, Mindset: The New Psychology of Success (New York: Ballantine Books, 2006).

Ibid at 6 .

Ibid at 7

Ibid at 32-39.

Ibid, ch 8.

For example, the University of Colorado Law School offers a weekly mediation practice open to members of the law school community. It also has offered a voluntary year-long class in the first year called the "Telos Project," focused on providing first year law students with a consistent meeting space in which to reflect on, and engage with, transformations they experience during their first year. The Telos Project includes an introduction to a full range of mindfulness practices. One of the most expansive mindfulness projects can be found at the University of Miami School of Law where Scott Rogers directs the Mindfulness in Law Program ("Mindfulness in Law Program,” online: Miami Law, $<$ http://www. miamimindfulness.org/>). Similarly, lawyers and legal educators have started to gather more regularly to investigate mindfulness and the law. In particular, over the last handful of years, the University of California at Berkeley Law School has hosted two conferences considering mindfulness and the law ("Berkeley Initiative for Mindfulness in Law," online: Berkeley Law <http://www.law. berkeley.edu/mindfulness.htm>). 
of pressure rather than unconstrained reactivity. ${ }^{22}$ Similar to Schön's idea that reflective practice unveils new information, new frames, and new responses, mindfulness practices allow for fuller attention to information and create time and space for discerning a range of responses. The mindset of mindfulness understands that learning is more capacious and deep if the mind can monitor and attend to information and stimuli more thoroughly, and if decision making is discerning, not reactive, and habituated.

\section{WHERE DO CLINICS FIT INTO THE CONVERSATION?}

Under the “practice proven,” technical “practice ready,” and mindset approaches, clinics (and other forms of experiential learning) have heightened importance. For the "practice proven" folks, clinics are the most robust chance for students to actually be lawyers before they graduate. The more clinics can replicate what actual practice settings look like, the better - positively, because new graduates will be able to perform more like early mid-level lawyers, and, self-interestedly, because legal employers can avoid almost all training costs. To reach those results, clinics should prioritize choices such as taking the volume of clients that students will see in actual practice settings (private, non-profit, or government), and have students perform tasks that they would in "real life," like keeping time in ten minute increments. For the "practice proven” folks, clinics become a magic bullet because they are the sites in law school that can be turned most quickly and easily into modest replicas of existing legal work settings. The ails of legal education would be cured if law schools just built out more and bigger clinics. To use a baseball metaphor, for the "practice proven" folks, every clinic should be a “Triple A” team for some major-league legal employer.

For the technical "practice ready" folks, clinics are a magic bullet because when students are working for actual clients on real cases or projects, it is easy to construct a checklist of multiple technical skills that should have been practiced over the course of the representation. That contrasts to the limited number of tasks they often are able to check off from a substantive law lecture class focused on content coverage.

For example, in a typical lecture class on business organizations, students can check off that they practiced the skill of assimilating black letter law about business structures, and that they practiced the skill of assimilating knowledge by reading cases and maybe by analyzing some statutes. However, students enrolled in a business start-up clinic likely will be able to check off technical skills such as developing or understanding a business plan, completing business formation documents required by a secretary of state's office, creating an employee handbook, or developing a pitch for start-up funding. Thus, for the technical "practice ready" folks, the promise of clinics is that they offer up lengthier and more varied checklists. Under the technical "practice ready" approach, more is always better.

For the mindset "practice ready" folks, clinics are a magic bullet because of the way in which clinical pedagogy has developed. Clinicians have drawn capaciously from the ideas I mentioned above, including Schön's descriptions of reflective practice. Clinicians focus on 
learning techniques and learning environments that ask students to see mistakes and failures as opportunities to improve mastery instead of as indicators of lack of ability. ${ }^{23}$ Clinicians also focus on techniques and environments that ask students to think through how to transfer the particular knowledge they have learned in one setting to another related setting. ${ }^{24}$ Clinicians have embraced attention and discernment techniques, like mindfulness practices, as one of many opportunities for students to actually experience a "growth" mindset and move away from the idea that their capabilities are innate or fixed. Clinicians have rightly been proud of the special care and attention they have brought to their teaching and to their students' development as attorneys. Under the growth mindset approach to "practice ready," clinics are a magic bullet because they are magic. The additional implicit conclusion often drawn is that clinics are the only possible sites of magic in law school.

The challenge that results from the above conversations about clinics is that, for good or for bad, clinics are set up as if they were the only real magic bullet for reforming teaching in law school. Other suggested teaching reforms, such as adding experiential exercises into traditional lecture courses, become preliminary training moments for the capstone experience of a live-client clinic. It is the capstone clinic, however, where the "real action" is at.

That pressure is unhelpful and unproductive particularly because it suggests that legal education can be reformed in an atomized way. It means the reform narratives likely sound something like these:

- Thank goodness we already have a clinical program at our law school. Now all we have to do is expand it. We seem to have a lot of real estate development going on in the area, and people always are going to need help with divorces. So, let's add a real estate clinic and a family law clinic.

- Thank goodness we can expand our clinical program. I should continue to focus on covering as much content as possible in my lecture class on [X] subject. The more content I cover, the more substantive law a student will know before she takes a clinic, and that will be helpful.

- Thank goodness we have clinics. It's too bad that clinics are small classes with limited enrollment. We'll increase the clinic class size to make sure that more of our students can graduate having taken a clinic. Students can still get the experience of a small class by taking a seminar.

- Thank goodness we have clinics. There is so much need in the community for free legal services. It will be a win-win if the clinics take more cases so that the students can see more kinds of lawyering and practice more kinds of tasks. We should try and rival the local legal aid and public defender offices in terms of the amount of cases we handle. 
The possible narratives could go on and on. I have only given narratives that reflect support for clinics. The skeptics have their own robust set of narratives, including that clinics cost too much, are pedantic about technical skills, and are inattentive to the importance of theory and policy. Further, each narrative usually carries a grain of truth so the conversation quickly moves into a tit-for-tat debate, thus ensuring that little actual reform can happen.

If I am correct that one of the key failures of the conversation is that it is atomized, then what might it mean to consider a law school as a learning ecology? I turn to that idea in the next section.

\section{WHAT IS A LEARNING ECOLOGY AND WHAT WOULD IT MEAN TO CONSIDER A LAW SCHOOL AS ONE?}

By learning ecology, I mean to evoke a concept of a connected, interdependent system. Nodes in the system do not, and cannot, stand alone. Further, each part of the system understands what the other parts do, even though some parts may specialize or emphasize certain functions. Parts communicate regularly with each other, and collaborate when helpful. The system itself has a set of common goals, and the work of the nodes can be tied clearly to one or more of the systemic goals.

A key feature of a learning ecology is that it is sensitive to individual developmental learning needs. However, that does not mean it is linear. A learning ecology creates numerous, often branching, often reconnecting pathways for students to follow as they acquire knowledge. There is no one right way to move through the ecology, although there may be a list of expected learning experiences that should be completed before a student may graduate. A learning ecology embraces the idea that "the teacher appears when the student is ready" 25 - in other words, that a necessary condition for a student to learn fully is that the student believes that she is ready for, or will benefit from, the particular learning experience. Of course, the ecology also provides a student advice and guidance about choosing various pathways, and presses a student not to be complacent about her choices. In other words, the student is not left to divine her way forward without help, but the ecology offers her a fulsome set of choices and supports and challenges her in crafting her own particular path.

Further, learning pathways always are embedded in some kind of context so that students experience content in action. The learning ecology that I am describing is inspired by the legal realist concern that content unmoored from actual application is of little use. ${ }^{26}$ But, it is also central to the learning ecology that what counts as an "application” is capacious.

For example, an application could include taking content and asking a student to craft the kinds of documents a lawyer might use to achieve a goal for an individual client: "If Ms. Smith wanted to make sure the title to her house transferred to her daughter upon Ms. Smith's death, draft at least two different kinds of documents for achieving that goal." An application also could include understanding how content reflects normative choices: "When 
the law defines discrimination in a particular way, and we look at the kinds of lawsuits that succeed under the law, what do we discover about who the law favours as between employers and employees?” Of course, applications could include work on actual cases or projects, but those cases and projects themselves could have different contexts. For example, students in a family law clinic might generally help individuals adopt children, or those students might focus on helping lesbian, gay, bisexual, and transgender adults adopt children in states in which such adoptions still are disfavored. Each context illuminates the content of family law in different ways.

The fact that a learning ecology, by definition, must be interconnected and interdependent leads to some related consequences. The first consequence is that no one part of the ecology can be a magic bullet — clinics are not a magic bullet, externships are not a magic bullet, reforming the first year curriculum is not a magic bullet. Relatedly, every part of the ecology must be able to flex, give, and adjust — dynamism and change are inherent in the system (although that does not mean change needs to be radical at all times).

The next consequence is that all of the participants in the learning ecology are interconnected and interdependent, and, thus, must flex and give. That pushes against the current expectations at most law schools for its participants. For example, at most law schools, the first year is tightly scripted for students. While students have more freedom in their second and third years to choose their learning paths, there are often informal, rigid scripts that students unquestioningly embrace. Students might learn an informal script that they can get more "prestigious” legal jobs if they clerk for a federal appellate judge, and to do that they must participate on law review. Or, students may informally learn that if they want to work in the local public defender's office, the only way they will get a job offer is to participate in their school's criminal defense clinic. Or, students hear that it will be easier for them to pass the bar exam if they take as many "bar" courses as possible. The informal scripts are presented as capital-T “Truth” and lack any nuance or reflective consideration.

Similarly, faculty are accustomed to prioritizing their individual interests, including their interests about which classes they teach and how they teach. At most law schools there is not a sustained, faculty-wide conversation about teaching, learning, or learning theory. There also is no sustained, systemic collaboration across all faculty about teaching or learning, and faculty-wide conversations about teaching are often limited to discussions about content coverage.

Of course, the above descriptions are general and broad. By this point in time, it would be rare to find a law school where one would find absolutely no examples of at least a subgroup of faculty concerned about learning theory and collaboration. In fact, those areas are ones in which faculty involved in clinical teaching have long been the vanguard. Similarly, one can point to many wonderful, specific examples of innovative courses in which multiple faculty members collaborate and make thoughtful and reflective pedagogical choices. ${ }^{27}$ However, to think of a law school as an ecology of learning requires fuller and 
more comprehensive participation. It is not enough that Professor $\mathrm{X}$ and her students are innovating, nor that Professors $\mathrm{X}$ and $\mathrm{Y}$ and their students are innovating. An ecology requires more.

I will explore later the questions of how much more, and whether an ecology can be effective if it is created over time instead of wholesale at the start. Before getting to those questions, I return to the starting descriptions about ways law schools could transform how they teach in order to produce "practice ready" graduates. I have suggested that using the frame of a learning ecology helps us avoid the mistaken notion that there is one kind of magic bullet change that law schools can make. However, I hope that the learning ecology frame can be more useful than just saying there is no magic bullet. In order to do that, I have to be clear about the telos, or end goal, of a law school learning ecology.

\section{WHAT SHOULD BE THE GOALS OF A LAW SCHOOL LEARNing ECOlogy AND WHAT DoES THAT MEAN IN ACTION?}

Part of what fascinates me about the "practice ready" conversations is the way in which each variation prompts me to respond, "Yes, but ..." In other words, each perspective includes at least one feature that seems important to include as part of a law school ecology of learning.

For example, one goal of the ecology should be that students acquire some amount of technical knowledge about the law (including technical knowledge about sources of law) as well as acquire the competency of learning how to find additional technical knowledge from various sources. Thus, some focus on content is important. Similarly, another goal of the learning ecology should be that students test out knowledge "in action" so that they can develop applied expertise - not only applied, technical expertise, but also the kind of expertise that has been called "practical wisdom.” To do that, students need to complete lawrelated tasks, and need to be situated in settings that, in fact, model "real” legal settings, at least along some relevant dimensions. Further, law always has been dynamic, fluid, and changing - through court-based change, legislative change, changes in custom and practice, and the like. Thus, another goal of the learning ecology should be to inculcate a mindset that includes the habit of reflective thought, is at ease with change, and sees change as opportunity more than risk. Finally, embedded within each of the above goals is a range of normative visions about the role of the lawyer (and law) in society. An ecology of learning should have a goal of making those normative visions transparent to students, investigating the commonalities and conflicts between the visions, and asking students to make intentional, thoughtful choices about which vision they expect to adopt as they move into the legal profession.

By using the frame of a learning ecology with its flexible, dynamic architecture of an interconnected system, the frame easily embraces multiple goals, even conflicting goals. In a flexible, dynamic, and interconnected system, conflict does not create a blockade between parts of a system. Instead, it stimulates activity — conversation, exploration, and adaptation. 
Conflict is nothing more than one kind of input into the system - no better or worse than any other input. For example, one normative vision about the role of the lawyer in society is that she is an instrument for preserving and protecting the rule of law, and for facilitating a lay person's participation in rule-of-law-abiding institutions like courts. ${ }^{28}$ Another normative vision about the role of the lawyer is that she is an instrument for potentially radical social change and has the goal of disrupting existing institutions of power and subordination. ${ }^{29}$ An ecology of learning need not choose between such goals, but it does need to illuminate both goals for students, and provide opportunities for students to directly reflect on such goals, and to have opportunities to experience what each goal might look like in action for a lawyer.

Further, an ecology also easily embraces the idea that its different parts can focus more on one or some systemic goals rather than others. Different parts of the ecology can have different areas of expertise so long as all parts remain connected, interrelated, and in conversation with each other. If one part of the system is best suited to teaching technical content, then that part also needs to include information about how technical content relates to technical action, practical wisdom, and normative visions of the role of the lawyer.

There is one more step to take in order to build an ecology of learning. That is to take the goals of the ecology and understand what actions demonstrate that a student has learned the multiple features or facets of the goal. In other words, how would a student or another interested observer like a potential employer be able to discern that a student has retained a sufficient amount of technical content about the law, or is proficient in a sufficient amount of activities that demonstrate an ability to put content into action, or shows a sufficient level of thoughtfulness about the normative role of the lawyer and so forth?

Before translating goals into some set of more particulars, I want to take a moment to talk terminology. Historically in law schools, we often have said that we reach our teaching goals via two paths - either by teaching the "law" or by teaching legal "skills."30 "Law" courses have mostly been lecture courses using casebooks. "Skills" courses have been everything else, from first-year legal writing to simulation courses about topics like deposition-taking or negotiation, to full-year, live-client, clinical courses that might focus on individual cases or on systemic social change. Further, as has been well illuminated, the distinction between law and skills has mapped directly onto distinctions between high and low status among faculty. ${ }^{31}$ Those distinctions understandably have generated challenging, and at times, acrimonious exchanges between "law" faculty and "skills" faculty about whose teaching is

See e.g. W Bradley Wendel, Lawyers and Fidelity to Law (Princeton: Princeton University Press, 2010); Daniel Markovits, A Modern Legal Ethics: Adversary Advocacy in a Democratic Age (Princeton: Princeton University Press, 2008).

29 See e.g. Gerald P López, Rebellious Lawyering: One Chicano’s Vision of Progressive Law Practice (Boulder: Westview Press, 1992).

$30 \quad$ See e.g. Bryan L Adamson, et al, "Clinical Faculty in the Legal Academy: Hiring, Promotion and Retention” (2012) 62:1 J Legal Educ 115 (using the term "skills faculty” to speak about faculty who teach classes other than podium, lecture courses).

31 Ibid (noting the problematic hierarchies that exist between clinical and non-clinical faculty members at 135-38). 
more important or more potent to students. ${ }^{32}$ Of course, thoughtful scholars and teachers have regularly reminded us that an either-or perspective is inaccurate and unhelpful. ${ }^{33}$ But, the law versus skills conversation now is so freighted that it seems useful to jettison the terms.

Over the last handful of years, researchers, teachers, and legal professionals have begun to talk about a range of "competencies” that effective lawyers demonstrate. I expect readers already will be familiar with one of the seminal studies in the area — the 2008 research paper by Marjorie Schultz and Sheldon Zedeck — which identified 26 competencies demonstrated by effective practicing lawyers. ${ }^{34}$ Schultz and Zedeck organized the 26 competencies under eight "umbrella" categories, including topics such as research and information gathering, communications, conflict resolution, and character. ${ }^{35}$ Schultz and Zedeck generated their list of 26 competencies over the course of two separate research projects collecting data from practicing attorneys who had graduated from law school between 1970-2002. ${ }^{36}$ The methodology that Schultz and Zedeck utilized is sophisticated and results in an empirically well supported list.

Some have found that 26 competencies are slightly unwieldy and have suggested that it might be more practical to focus on a shorter list, such as six competencies. ${ }^{37}$ Forwardleaning law firms have developed associate evaluation models based on competencies tailored to a firm's particular practice area or culture. ${ }^{38}$ While the varieties among competency models are useful to explore, the most interesting feature for the purposes of this article is that the conception of competencies has provided a way to mend together learning about "law" and learning about "skills."

For example, in the Shultz and Zedeck competency list, one can find a specific competency of analysis and reasoning and another of writing. ${ }^{39}$ The first traditionally has been considered learning the law, while the second traditionally has been considered learning a skill. Further, the Shultz and Zedeck list includes other competencies that law schools generally list under "law" courses, but which could implicate soft skills depending on how a faculty member chooses to teach the course. The competencies listed under the umbrella category of “character," such as honesty, integrity, and passion are good examples of items that might be labeled "soft skills,” but which can be addressed in a law class on legal ethics. ${ }^{40}$

The blogosphere is an easy space in which to find recent examples of such exchanges. See e.g. Eric Miller, "The False Dichotomy Between Practice (Doctrine) and Academics" (11 February 2013), online: PrawfsBlawg <http://prawfsblawg.blogs.com/prawfsblawg/2013/02/the-false-dichotomy-betweenpractice-doctrine-and-academics.html>; Michael JZ Mannheimer, "What We Talk About When We Talk About Skills”(12 February 2013), online: PrawfsBlawg <http://prawfsblawg.blogs.com/prawfsblawg/ 2013/02/what-we-talk-about-when-we-talk-about-skills.html>.

33 See e.g. Nancy B Rapoport, "Rethinking U.S. Legal Education: No More 'Same Old, Same Old'” (2013) 45:4 Conn L Rev 1409 (reframing the conversation as one about creating developmentally-appropriate building blocks of learning at 1414).

34 Marjorie M Shultz \& Sheldon Zedeck, Final Report: Identification, Development and Validation of Predictors for Successful Lawyering (September 2008), online: Berkeley Law <http://www.law. berkeley.edu/files/LSACREPORTfinal-12.pdf> [Shultz \& Zedeck, Final Report].

Ibid at 26.

Ibid at 24-27.

See William Henderson, "What every law student needs to excel as an attorney: Introducing the Fromm Six,” The National Jurist (March 2013) 20, online: Nxtbook Media <http://www.nxtbook.com/ nxtbooks/cypress/nationaljurist0313/\#/20>.

38 See e.g. Bryn Vaaler, “Codifying Competencies,” Law Firm Partnership \& Benefits Report (January 2005) (describing an competency-based associate evaluation model).

$39 \quad$ See Shultz \& Zedeck, "Predicting Lawyer Effectiveness," supra note 5 at 630.

$40 \quad$ Shultz \& Zedeck, Final Report, supra note 34 at 27. 
Thus, one of the lovely results of moving to the language of competencies is that it offers the possibility of letting go of the old, unhelpful, divisive frame of law versus skills. Further, the idea of competencies maps nicely onto the idea of a learning ecology. One could situate competencies throughout a learning ecology, with overlap, interconnectedness, and interdependence. One might think about teaching a course in contracts by first specifically identifying certain competencies on which to focus. Those might include researching the law, writing, listening, negotiation, and building relationships with clients. One's colleague teaching a first year course on the foundations of the administrative state might include almost all of the same competencies, but placed in a different context. If the ecology is working well, both teachers would explicitly reflect with their students on how contexts matter to a competency. What goals does writing usually have when one is drafting a private contract between two parties, and how are those goals the same or different if one is drafting for broader societal purposes? Is the role of black letter law the same in a private setting as in a public one? Does being a lawyer for a private party require respecting individual autonomy in the same or different ways than being a lawyer for a government agency?

The above positive dimensions that come from adopting the term "competencies" make it a satisfying fit for a frame of a learning ecology. If I could build out one other dimension more explicitly, it would be to make clear that competencies develop over time and are not "off or on." In other words, a competency is not like a law license - either one has a license or one does not. Instead, a competency is measured across a spectrum, from beginner to expert. Even experts must continue to mould and refine their competencies. Further, by understanding competencies as something other than "off or on," students might be better able to resist the idea that they are studying to learn the one right answer, or to learn the one right way to "do it," or that black letter law comes in an unchangeable and noncontextualized form. If there is a quick phrase to capture that idea of dynamism within competencies, it might be something like "complacency and certainty are the enemies of competency."

Settling into the rubric of competencies, I want to return to the issue of mapping a law school learning ecology by looking at how competencies currently are distributed across the ecology, and whether that distribution builds connectivity and relationality, is dynamic, is non-linear, and includes a multitude of interwoven learning pathways. Because I expect most readers already to have started to conjure their own law school's map, I lead with my own conclusions about what a typical learning map looks like. Of course, as with any set of generalized conclusions, one can find exceptions - within individual law schools and across institutions. Those exceptions are proof of the possibility of good, productive change. However, I think the generalized map I present below captures the more dominant architecture.

The general map reveals that there is a very small cluster of competencies on which classes focus in the first year. Using the Shultz and Zedeck list, the first year includes exposing students to: (1) some parts of analysis and reasoning (the first year likely does not include the "advice giving" part of the competency); (2) a highly contained version of fact finding; a somewhat contained version of researching the law; and, (3) some limited forms of writing, speaking, and listening. Almost none of the first year places law in action (other than the limited context disclosed by appellate opinions). There is little intentional 
integration or connection between courses. There is little dynamism (that is, teachers rarely vary from their preplanned script for the semester). There is no room for developmental differences or different learning paths (with some exceptions at a very small number of schools). Only a small number of schools make intentional, thoughtful efforts related to professional formation and make transparent for students the normative choices about possible roles of the lawyer.

In the second and third years, there still is a heavy focus on the same small cluster of competencies from the first year. There still is little integration or connection between courses. There still is little dynamism. There are opportunities for students to see law in action, but almost all those opportunities come up through externships outside the law school, through simulation courses, or through clinical courses. There still is little room for developmental differences as faculty preclude choice through prerequisites or because student practice rules limit opportunities to certain students.

If we take the features of a learning ecology seriously, the above map suggests that we should be looking at change throughout all three years of law school. Many commentators have suggested that law schools do a good job in the first year by focusing on teaching students how to discern the law from cases and how to start comparing and contrasting cases. ${ }^{41}$ However, as others have noted, an unfortunate and extremely negative consequence of the narrow first-year focus is that we also teach students to think erroneously that only a very limited set of competencies matter in lawyering. ${ }^{42}$ As many others also have noted, we reinforce that focus with the way we grade students, placing almost all weight on a timed, final exam. ${ }^{43}$ I am certain that none of what I have said is new or surprising. Furthermore, there already are law schools that have sustained efforts in place to address several of the negative features of the first year. ${ }^{44}$ So, does the frame of a learning ecology open up any new ways forward?

I suggest that it does by helping to expand the focus from changes just in content of the first year (that is, adding a course on international law or client counseling or professional formation or the regulatory state). All of those content changes are important, and schools that have not yet considered such changes need to do so. However, a learning ecology stimulates other kinds of efforts as well. For example, to demonstrate interconnectedness and relationality in the law and between competencies, first-year faculty could develop a set of shared themes or meta-conversations that each of them build into their courses. They would intentionally and explicitly talk to students about what those students are learning in other courses and make connections within and between courses. A theme might be how the law attends to human relationships and how it does or does not consider the role of emotions as

$41 \quad$ See e.g. Ian Weinstein, "Financial Retrenchment and Institutional Entrenchment: Will Legal Education Respond, Explode, or Just Wait it Out? A Clinician’s View” (2013) 41:1 JL \& Pol’y 61.

42 See e.g. Rapoport, supra note 33 (opining that there needs to be a developmental cycle to the three years of law school and discussing how the current first year curriculum might fit in, but cannot be viewed in isolation at 1417-20).

$43 \quad$ See Carasik, supra note 6 at 780.

44 Some examples include Northeastern School of Law’s year-long, first year course, "Legal Skills in Social Context," online: Northeastern School of Law <http://www.northeastern.edu/law/experience/ lssc/index.html>; NYU Law School’s “Lawyering Program,” supra note 27; Indiana University School of Law’s first year course called, “The Legal Profession,” online: Indiana University School of Law $<$ http://law.indiana.edu/degrees/jd/curriculum.shtml $>$. 
a part of relationality. Or, a theme might be the tensions between individual choice and autonomy and social order. My point here is not to settle on the right themes, but only to suggest that taking seriously the idea that an ecology must be connected reveals other modifications in addition to changing the substantive law focus in courses.

Similarly, taking seriously an ecology's requirement for dynamism and application (that is, law "in action"), in every course students would work with some primary materials that form the basis for the substantive law area. It will be straightforward to come up with materials in some areas, like contracts, where every student would likely have his own examples - the lease for the student's apartment, the cell phone service contract, and the like. In other areas, it might take a bit more imagination. In torts, students could be assigned to walk around campus for an hour taking pictures of features they see that might give rise to tort liability (such as the cracked and uneven sidewalk, the parked delivery truck with its back end sticking out into the street, and so on). Maybe students could exchange photos and work in small groups to identify issues from class raised by the photos. In civil procedure, students could create their own family tree and assess for each family member which states might be able to exercise personal jurisdiction over the family member based on that member's work activities.

Again, my point is not to come up with the right activity through which to explore law in action, but only to demonstrate that it likely is not as hard to do as we worry about. Further, my examples intentionally are not about document drafting. I worry that the current conversation about infusing traditional lecture classes with more "experiential” learning has somewhat too often become a conversation only about document drafting. Drafting documents is an extremely important way for students to put their substantive law knowledge in action. Document drafting triggers students to use multiple competencies at the same time. To be done well, it is a labor-intensive teaching method, however. That intensity may be discouraging for faculty, and if they think that drafting is the only possibility for law-inaction, the result is that nothing changes in their teaching. However, if smaller, less intensive, law-in-action experiences are available, and if faculty can trust that the larger ecology of learning will provide other more intensive, law-in-action experiences, then faculty should feel more comfortable experimenting with smaller changes in their classes. Finally, in my examples I have focused on the first-year curriculum, but one can take any lecture course in which the current focus is on content coverage and adjust it similarly.

Let me return now to clinics. As my earlier description suggested, clinical faculty have created a pedagogy within clinics that contains many of the features of a learning ecology. Clinical pedagogy attends to a wide set of competencies, embraces interconnectedness, relationality, and context. I think it is fair to say that clinical programs are usually wonderfully vibrant learning ecologies. However, they also are usually learning ecologies within themselves and are not well-connected to learning outside of the clinic. That result has come about for several well-known reasons. Clinical programs were added on to most law schools well after schools opened their doors. ${ }^{45}$ Law schools often did not hire clinical faculty onto the tenure track, and paid clinical faculty less than tenure-track faculty. ${ }^{46}$ 
Clinical faculty were interested in, and motivated by, learning theories outside of the law, and developed a unique pedagogy for clinics as compared to lecture classes. ${ }^{47}$ Finally, law students found solace in clinical programs and treasured clinical spaces as their safe haven in law schools. Thus, students relished that clinical programs felt separate from the rest of law schools.

The result of clinics being isolated from the rest of law school is that they reinforced the idea of learning as atomized and disconnected, even if the actual learning within the clinic was connected and relational. In the most unhelpful case, students have been encouraged to believe that the only learning of value in law school happens in a clinical program. Just like every other teacher within a law school, a teacher in the clinic needs to be in conversation with colleagues across the curriculum, needs to help students make connections between their clinic learning and learning in other courses, and needs to help students discern what competencies they are or are not introduced to in their clinical experience. As with every descriptive point I have made in this article, there are already vibrant examples of the practices I am hoping for - there are faculty who now regularly teach in and outside of the clinic, and who are trying to build a school-wide learning ecology. Those colleagues already challenge each of us to step into the opportunities.

That call to see the current environment as full of opportunity instead of full of hardship does bring us back to the questions I posed earlier of how widespread an ecology must be to be effective and whether it can be created over time instead of wholesale. Or, to put the question into one of the themes of this article, "if there are no magic bullets, is there at least a magic wand?” Given how readily one can already find disagreement about the contours of the legal "crisis" and what appropriate solutions may be, there assuredly is no magic wand. Thus, the practicalities dictate that the way forward will have to be incremental. Bill Henderson has assessed that the incremental way forward is the " 12 percent solution." "48 As Henderson argues, a law school interested in change can start by identifying the "coalition of the willing” faculty who are already committed to changing legal education, and are curious to innovate in their courses. ${ }^{49}$ In Henderson's estimation, that coalition likely encompasses about 12 percent of a faculty. ${ }^{50}$ If that 12 percent collaborates and pools knowledge and resources, then Henderson opines that should be enough to create notable, productive, and worthwhile change. ${ }^{51}$ The one caveat I would add as I think about my own proposed goal of creating a learning ecology is that the 12 percent must teach across the full range of the curriculum in a law school. It will not help for the 12 percent to teach only in the first year, or only in the clinical program, or only in small classes, or only in the legal writing program. To hope that the starts of a school-wide ecology can spread, those starts must be broadly distributed. Whether or not 12 percent of the faculty is a sufficient amount to create an ecology over time, I am not certain. But, given how clear is the need for change, I would rather take my chance on 12 percent than not take a chance at all.

Ibid at 16-18.

Henderson, supra note 7 at 503-506.

Ibid at 503.

Ibid.

Ibid at 503-506. 


\section{ConClusion}

I am an optimist. While my optimism does not allow me to believe in either a magic bullet or a magic wand, it does allow me to believe that genuinely useful change can, and is, coming to legal education. I want that change to be as potent for our students as it can be. But, I do not think that potent change must always be radical change. In this article I have suggested how reframing our view of a law school as being about a learning ecology can help us reform our teaching, often in modest and accessible ways. I also have suggested that clinics already do often provide our law schools with lovely models of self-contained learning ecologies, which we can easily mime. I am hoping if we can try harder to envision ourselves as an interconnected, interdependent, dynamic ecology, we can all let go of the burden of becoming the magic bullet. Then, we can see the possibilities of subtler, deeper change offering itself to us. 